\title{
Yield analysis of Physalis ixocarpa Brot. ex Hornem varieties under greenhouse and field conditions
}

\section{Bernabé Ignacio Ramos-López ${ }^{1 *}$ Yolanda Donaji Ortiz-Hernández ${ }^{1} \odot$ Isidro $_{\text {Morales }}{ }^{1} \odot$}

${ }^{1}$ Instituto Politécnico Nacional, Centro Interdisciplinario de Investigación para el Desarrollo Integral Regional (CIIDIR) Santa Cruz Xoxocotlán, 71230, Oaxaca, México. E-mail: ignacio.ramos1@yahoo.com. ${ }^{*}$ Corresponding author.

ABSTRACT: Physalis ixocarpa (husk tomato) is traditionally cultivated in Mexico, and nowadays the yield is low. In this study, four cultivars of husk tomato were evaluated, under greenhouse and field conditions. It was carried out a split-plot experimental design in a $4 x 2$ factorial arrangement. The large plot was the growth conditions and the small plot was the variety. The microclimate, soil and yield variables were recorded. In the field, the Integrated Photosynthetic Active Radiation (IPAR) was higher $12 m^{2} m^{-2} d^{-1}$ than in the greenhouse. The average temperature was slightly higher $1.18^{\circ} \mathrm{C}$ in the greenhouse and the average relative humidity was slightly higher $0.89 \%$ in the field. Plants grown in the greenhouse had lower negative values for the matric potential of the soil. Water consumption and water use efficiency were 10.31 and $53.43 \%$ higher in the greenhouse that in the field, respectively. The number of fruits and yield increased significantly in all varieties grown under greenhouse conditions.

Key words: horticulture, husk tomato, intensive production, Solanaceae, yield.

Análise de rendimento das variedades Physalis ixocarpa Brot. ex Hornem sob condições de estufa e de campo

RESUMO: A Physalis ixocarpa (Tomate de cáscara) é cultivada tradicionalmente no México. Entretanto, sua produtividade de frutos é considerada baixa. Neste estudo, avaliou-se quatro cultivares de Physalis ixocarpa cultivadas em ambiente protegido e a céu aberto. O delineamento experimental utilizado foi em blocos ao acaso no esquema de parcelas subdivididas com arranjo fatorial $2 x 4$. Foi alocado na parcela principal o fator ambiente de cultivo e na subparcela o fator cultivar. Foram analisadas variáveis climáticas de solo e a produtividade de frutos. A radiação fotossinteticamente ativa integrada (RFAI) no ambiente a céu aberto foi maior em $12 \mathrm{~mol} \mathrm{~m}^{-2}$ dia ${ }^{-1}$, em relação ao ambiente protegido. A temperatura média foi ligeiramente maior em $1,18^{\circ} \mathrm{C}$ no ambiente protegido e a umidade relativa foi ligeiramente maior em $0,89 \%$ a céu aberto. Os valores negativos do potencial mátrico do solo foram mais baixos no ambiente protegido. O consumo e a eficiência do uso da água foram, respectivamente, 10,31 e 54,43\% maiores no ambiente protegido, em relação ao ambiente a céu aberto. O número e a produtividade de frutos incrementaram, significativamente, em todas as variedades avaliadas nas condições de ambiente protegido. Palavras-chave: horticultura, Physalis ixocarpa, produção intensiva, Solanaceae, produtividade.

\section{INTRODUCTION}

Green tomato, tomatillo or husk tomato (Physalis ixocarpa Brot. ex Hornem) is a highlydemanded native vegetable from Mesoamerica. For the last three years, the husk tomato has been the fifth most economically important vegetable in Mexico. Most production is carried out by small farmers in less than one hectare plots. In 2014 , the total cultivated surface was of 44,000ha; their yield was $20 \mathrm{tha}^{-1}$ under irrigation and $14 \mathrm{tha}^{-1}$ under rain fed conditions (SAGARPA, 2016). Nonetheless, these yields are considered low and they could possibly increase by applying technologies such as greenhouses (LOPEZLOPEZ et al., 2009). The limitations for commercial greenhouse production of husk tomato: adequate greenhouses designed to meet the requirements for these species, and decent availability of varieties adapted to this production system (SANTIAGUILLO et al., 2009 and PONCE et al., 2012). As these authors pointed out, greenhouse production of husk tomato is a viable option due to market forces and to provide protection from ambient conditions such as extreme cold temperatures. RAMOS et al. (2002) obtained maximum yields of husk tomato grown under greenhouse conditions of $2.52 \mathrm{~kg} \mathrm{~m}^{-2}$ by using the CHF1-Chapingo genotype; SANTIAGUILLO et al. (2004) reported yields of $42.5 \mathrm{tha}^{-1}$ when they crosspollinated genotypes CHF1-Chapingo and Verde Puebla. However, PEÑA-LOMELI et al. (2014) reported that genotypes derived from the Rendidora variety yielded more under both conditions. In the last 
five years in Mexico, prices of commercial varieties of Physalis spp., for field-sowing, like Verde Puebla and Rendidora are similar and sometimes higher, than the price for S. lycopersicum L.; native species of Physalis spp. can triple that price. During periods when tomato prices are high, husk tomato (native or improved) is used as a substitute (VARGAS et al., 2015). Based on these facts, this research compared the yield response of four Physalis spp. varieties sowed in the field and under greenhouse.

\section{MATERIALS AND METHODS}

The experiment was conducted from September $18^{\text {th }}, 2015$ to February $7^{\text {th }}, 2016$ at Santa Cruz Xoxocotlán, Oaxaca, México. This place is located at $1530 \mathrm{~m}$ above sea level, $17^{\circ} 1$ ' $31^{\prime \prime} \mathrm{N}$, and $96^{\circ} 43$ ' 11 " W. Four husk tomato varieties, Tecozautla, Rendidora, Diamante and San Martin were germinated in 200-well polystyrene trays filled with $80 \%$ Sphagnum peat moss and 20\% Agrolite. Trays were watered daily with water containing 75,20 and $75 \mathrm{mg} \mathrm{L}^{-1}$ of $\mathrm{N}, \mathrm{P}$ and $\mathrm{K}$, respectively. Seedlings were transplanted to the field and to the greenhouse 30 days after germination (October $18^{\text {th }}$ ). Plant density was 1.5 plants $\mathrm{m}^{-2}$ in $1 \mathrm{mx} 23 \mathrm{mx} 0.30 \mathrm{~m}$ (WxLxH) rows. Every row was covered with black and silver plastic.

Physical properties of the soil were analyzed by following the Official Mexican Norm Standard NOM-021-RECNAT-2000 (SEMARNAT, 2016). The soil had a sandy texture (91\% sand, $2.7 \%$ litmus and $6.3 \%$ clay), an apparent density of $1.55 \mathrm{~g}$ $\mathrm{cm}^{-3}$, a field capacity of 8.5 , a wilting point of $3.5 \%$, and a basic filtration of $6.3 \mathrm{~cm} \mathrm{~h}^{-1}$. Irrigation was provided with ribbons and droppers at a flow of $1 \mathrm{~L}$ $\mathrm{h}^{-1}$ and a pressure of $0.8 \mathrm{~kg} \mathrm{~cm} \mathrm{~cm}^{-2}$. Nutritive solution was implemented according to URRESTARAZU (2004). The concentration in $\mathrm{mg} \mathrm{L}^{-1}$ of each element was as follow: N (250), P (60), K (300), S (200), Mg (75), Fe (3), Mn (0.5), B (0.5), Cu (0.1) and Zn (0.1). Soil humidity was monitored daily by a tensiometer placed in the center of the experimental area of the greenhouse and the field (Irrometer ${ }^{\mathbb{B}} \mathrm{SR}$, Irrometer Company, Riverside California, USA) according to the VILLALOBOS et al. (2004) method, and irrigation was applied when needed. Likewise, the water consumed was determined by the volumetric method cited by this author, measuring the volume of water applied through irrigation during the growing period. The water-use efficiency was calculated according to FLORES et al. (2007), OJODEAGUA et al. (2008) y HASHEM et al. (2011), as the ratio between yield $(\mathrm{kg})$ to the total amount water $\left(\mathrm{m}^{3}\right)$ use during the crop cycle.

A tunnel-type greenhouse, covered with $200 \mu \mathrm{m}$ thick transparent plastic was used. Ventilation was passive by using hand-powered windows: one towards the Zenith and two on the sides. Side windows allowed the entrance of bees and insects into the greenhouse. The field plot had the same dimensions as the greenhouse. An Apis mellifera beehive was placed outside the greenhouse to promote pollination according to PEÑA- LOMELI et al. (2014).

Temperature and relative humidity of the air was recorded at both conditions with Hobo Pro V2 data loggers $\left(\right.$ Onset $^{\circledR}$, Massachusetts, USA). Photosynthetically Active Radiation (PAR, $\mu \mathrm{mol} \mathrm{m} \mathrm{m}^{-2} \mathrm{~s}^{-1}$ ) was measured inside and outside the greenhouse, two sunny days every week, throughout the crop cycle. PAR readings were taken every hour from 8:00 to 18:00h by using a MQ-300 linear quantum sensor (Apogee ${ }^{\circledR}$ Instruments Inc. UT, USA). With the average hourly values of the PAR, the Integrated Photosynthetic Active Radiation (IPAR) was calculated according to FAUST (2002), because plant growth is determined in $\mathrm{mol} \mathrm{m}^{-2}$ day $^{-1}$ (KORCZYNSKI et al., 2002).

A split-plot experimental design was carried out in a $4 \times 2$ factorial arrangement with three replicates. The big plot was "the condition" (field and greenhouse), and the small plot was "a husk tomato variety" (Rendidora, Tecozautla, Diamante and San Martin). Each experimental unit was made up of four plants. Seven harvests were made, from December $10^{\text {th }}, 2015$ to February $7^{\text {st }}, 2016$. Fruits were counted, weighted on a digital scale (O'Haus Pionner ${ }^{\mathbb{B}}$ Corporation, USA), and measured on their equatorial diameter (according to the norm NMXFF-054-1982, for size and equatorial fruit diameter). Shoot thickness was measured with a digital caliper (Series 500, Mitutoyo ${ }^{\circledR}$ USA) and branch length was measured with a measuring tape $\left(\right.$ Stanley $\left.{ }^{\circledR}\right)$.

Analysis of variance and Tukey's mean comparisons $(\mathrm{P} \leq 0.05)$ were analyzed on each variable by using the $\mathrm{SAS}^{\circledR}$ software version 9.0 (STATISTICAL ANALYSIS SYSTEM, 2002).

\section{RESULTS AND DISCUSSION}

\section{Microclimate comparison}

Data showed significant differences, from 8:00 to 18:00h, between PAR inside and outside the greenhouse. The highest PAR occurred at 13:00h with $1700 \mu \mathrm{mol} \mathrm{m} \mathrm{m}^{-2} \mathrm{~s}^{-1}$ inside the greenhouse and $2250 \mu \mathrm{mol} \mathrm{m}^{-2} \mathrm{~s}^{-1}$ outside the greenhouse. P. ixocarpa 
Brot. ex Hornem plants cultivated in the field and in the greenhouse received an IPAR in average 42 and $30 \mathrm{~mol} \mathrm{~m}^{-2} \mathrm{~d}^{-1}$, respectively (Table 1 ). In the greenhouse was less than on the field due of the plastic covering. For the whole trial, PAR values followed this behavior, yet the lowest values surpassed the minimum required values for this vegetable $\left(19 \mu \mathrm{mol} \mathrm{m}^{-2} \mathrm{~s}^{-1}\right)$.

In the field $P$. ixocarpa Brot. ex Hornem plants received higher IPAR than those grown under the greenhouse (Table 1). Average monthly temperature and relative humidity under the greenhouse and on the field are shown in table (1). Temperatures in the greenhouse had an increase of 0.53 to $1.92^{\circ} \mathrm{C}$ with respect to the field; because inside the greenhouse the airflow is less due to the obstruct for plastic cover or mesh (VALERA et al., 2006). ADAMS et al. (2001) indicated that an increase in greenhouse temperature promotes growth, flowering and fruit production in tomato (Lycopersicum esculentum L.), and hinders attacks by pests and diseases (RODRÍGUEZ et al., 2011). Conversely, in October the average relative humidity was lower in the greenhouse with respect to the field, due to the higher temperature under the plastic cover (BURIOL et al., 2000).

Matric potential of the soil, water consumption and water use efficiency

Significant differences were reported in each variable for field and greenhouse conditions. Greenhouse soil reached the maximum negative value for matric potential, $-24 \mathrm{kPa}$ average, whereas this value was $-20 \mathrm{kPa}$ on the field (Figure 1). During the crop cycle, in the greenhouse were consumed 84L plant $^{-1}$; while $75.3 \mathrm{~L}$ plant $^{-1}$ were consumed in the field (Figure 2), which was $10.36 \%$ lower compared to the greenhouse, due to the increase in temperature and decrease in relative humidity (Table 1), this also to the greater number of fruits and yield (Table 2 and 3 ).

Water-use efficiency was $38.46 \mathrm{~kg} \mathrm{~m}^{-3}$ in the greenhouse, while in the field it was $17.91 \mathrm{~kg}$ $\mathrm{m}^{-3}$ (Figure 2), this due to high temperature and low relative humidity of the environment (Table 1).The greenhouse result in this study it was $28.13 \%$ higher than LOPEZ-LOPEZ et al. (2009) whose reported values of water-use efficiency of $27.64 \mathrm{~kg} \mathrm{~m}^{-3}$ when grown on plastic-covered fields. Plants grown at greenhouse had lower negative values for the matric potential of the soil. WANG et al. (2006) and ZHANG et al. (2011) indicated that water demand by any crop is tightly related to environmental factors, such as air temperature, radiation, and wind, that increase evapotranspiration in plants (HASHEM et al., 2011).

\section{Yield and its components}

Significant differences $(\mathrm{P} \leq 0.05)$ were reported for the varieties, conditions and the interaction between factors for the variables number of fruits per plant, total yield, equatorial diameter, and fruit weight (Table 2). The highest number of fruits (115.67) was collected in the greenhouse; Rendidora had the highest number of fruits, followed by Diamante, Tecozautla and San Martin. The lowest number of fruits (34.33) and the total yield was collected from the Tecozautla variety under field conditions. Rendidora, variety had the highest yield $\left(4.84 \mathrm{~kg} \mathrm{~m}^{-2}\right)$ under greenhouse conditions. Tecozautla variety produced type $B$ fruits $(4.7-5.4 \mathrm{~cm}$, based on the NMX-FF-54-1982 standard), under field and greenhouse conditions. The mean fruit size was $4.9 \mathrm{~cm}$

Table 1 - Climate conditions for P. ixocarpa Brot. ex Hornem cultivated under greenhouse and field conditions for five months. Santa Cruz Xoxocotlán, Oaxaca, México. 2015/16.

\begin{tabular}{|c|c|c|c|c|c|c|}
\hline \multirow{2}{*}{ Months } & \multicolumn{2}{|c|}{ 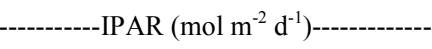 } & \multicolumn{2}{|c|}{------Temperature $\left({ }^{\circ} \mathrm{C}\right)-------$} & \multicolumn{2}{|c|}{--------Relative Humidity (\%)-------. } \\
\hline & Greenhouse & Field & Greenhouse & Field & Greenhouse & Field \\
\hline Oct. & $34.98 \pm 2.51$ & $48.98 \pm 2.90$ & $22.17 \pm 1.77$ & $20.25 \pm 0.81$ & $66.05 \pm 6.45$ & $72.93 \pm 7.28$ \\
\hline Nov. & $30.42 \pm 2.35$ & $42.59 \pm 2.15$ & $20.26 \pm 2.06$ & $19.33 \pm 1.97$ & $68.66 \pm 3.57$ & $68.93 \pm 3.54$ \\
\hline Dec. & $28.9 \pm 1.88$ & $40.46 \pm 2.56$ & $18.96 \pm 1.42$ & $18.43 \pm 1.33$ & $66.19 \pm 2.71$ & $65.36 \pm 2.77$ \\
\hline Jan. & $27.38 \pm 2.10$ & $38.33 \pm 2.24$ & $18.01 \pm 2.11$ & $16.86 \pm 2.04$ & $56.23 \pm 4.95$ & $54.49 \pm 5.69$ \\
\hline Feb. & $28.32 \pm 2.35$ & $39.65 \pm 1.89$ & $20.77 \pm 1.45$ & $19.35 \pm 1.13$ & $55.09 \pm 4.06$ & $54.92 \pm 4.76$ \\
\hline Mean & 30.0 & 42.0 & 20.03 & 18.85 & 62.44 & 63.33 \\
\hline
\end{tabular}


Table 2 - Genotype by environment interaction and its effect on P. ixocarpa Brot. ex Hornem characteristics. Santa Cruz Xoxocotlán, Oaxaca, México. 2015/16.

\begin{tabular}{|c|c|c|c|c|c|c|c|c|c|c|c|c|}
\hline \multirow{2}{*}{ Cultivar } & \multicolumn{2}{|c|}{$\begin{array}{c}\text { Equatorial diameter } \\
(\mathrm{cm})\end{array}$} & \multicolumn{4}{|c|}{---------Fruit weight (g)------------ } & \multicolumn{3}{|c|}{---------Fruit plant ${ }^{-1}$--------- } & \multicolumn{3}{|c|}{---Total yield $\left(\mathrm{kg} \mathrm{m}^{-2}\right)---$} \\
\hline & Greenhouse & Field & CV (\%) & Greenhouse & Field & CV $(\%)$ & Greenhouse & Field & CV (\%) & Greenhouse & Field & CV (\%) \\
\hline Tecozautla & $4.41 \mathrm{~B}^{1} \mathrm{a}^{2}$ & $4.90 \mathrm{Aa}$ & 8.08 & $41.65 \mathrm{Ba}$ & $52.29 \mathrm{Aa}$ & 20.89 & $79.67 \mathrm{Ab}$ & $34.33 \mathrm{Bc}$ & 30.38 & $4.06 \mathrm{Ab}$ & $2.73 \mathrm{Ba}$ & 27.91 \\
\hline Rendidora & $4.16 \mathrm{Ab}$ & $3.84 \mathrm{Bc}$ & 3.75 & $30.46 \mathrm{Ab}$ & $26.10 \mathrm{Bc}$ & 5.02 & $115.67 \mathrm{Aa}$ & $58.00 \mathrm{Ba}$ & 8.64 & $4.84 \mathrm{Aa}$ & $2.10 \mathrm{Bb}$ & 10.66 \\
\hline Diamante & 4.21 Aab & $4.24 \mathrm{Ab}$ & 8.21 & $34.68 \mathrm{Ab}$ & $35.19 \mathrm{Ab}$ & 22.22 & $81.67 \mathrm{Ab}$ & $62.00 \mathrm{Ba}$ & 19.04 & $3.95 \mathrm{Ab}$ & $2.73 \mathrm{Ba}$ & 12.29 \\
\hline San Martin & $3.99 \mathrm{Ab}$ & $4.22 \mathrm{Ab}$ & 4.94 & $32.39 \mathrm{Bb}$ & $37.29 \mathrm{Ab}$ & 22.04 & $78.00 \mathrm{Ab}$ & $49.33 \mathrm{Bb}$ & 29.47 & $3.07 \mathrm{Ac}$ & $\begin{array}{l}2.40 \\
\mathrm{Bab}\end{array}$ & 23.94 \\
\hline CV (\%) & 6.9 & 6.6 & & 22.14 & 38.71 & & 22.03 & 19.06 & & 27.35 & 28.56 & \\
\hline
\end{tabular}

${ }^{1}$ Uppercase letters for row analysis, ${ }^{2}$ Lower-case letters for column analysis; ${ }^{1 \text { and } 2}$ Same case letter in each column or row are not statistically different, Tukey $(\mathrm{P} \leq 0.05)$; $\mathrm{CV}$ : coefficient of variation.

and $52.29 \mathrm{~g}$ for the field grown plants, and $4.41 \mathrm{~cm}$ and $41.65 \mathrm{~g}$ for the greenhouse plants. Varieties Diamante, San Martin and Rendidora produced size C fruits (3.9 to $4.6 \mathrm{~cm}$ in equatorial diameter, based on the NMXFF-54-1982 standard).

\section{Harvests and production precocity}

Total yield from the seven harvests from the P. ixocarpa Brot. ex Hornem plants showed significant differences $(\mathrm{P} \leq 0.05)$ among varieties and conditions (Table 3). Rendidora under field and greenhouse

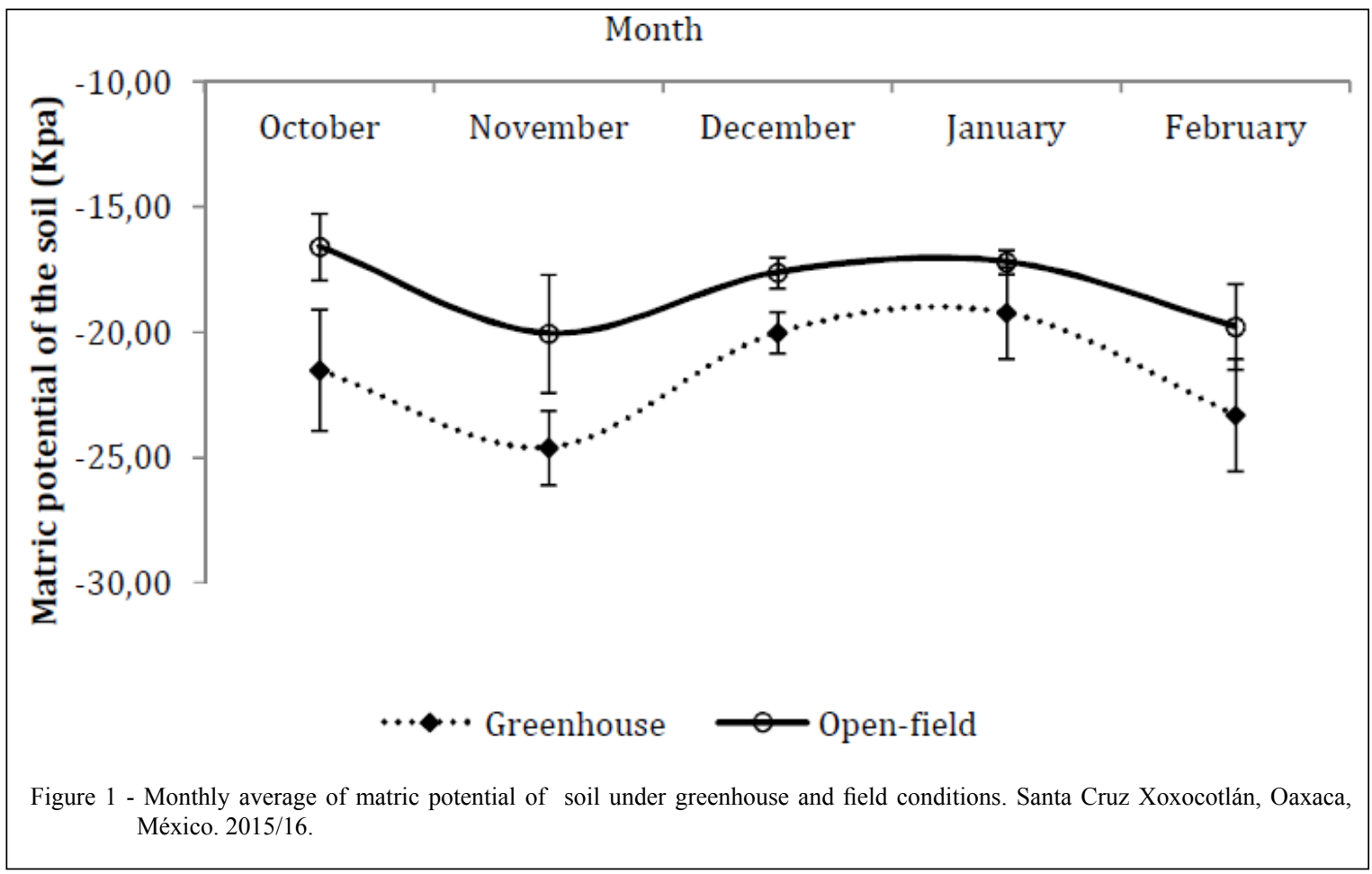

Ciência Rural, v.48, n.11, 2018. 


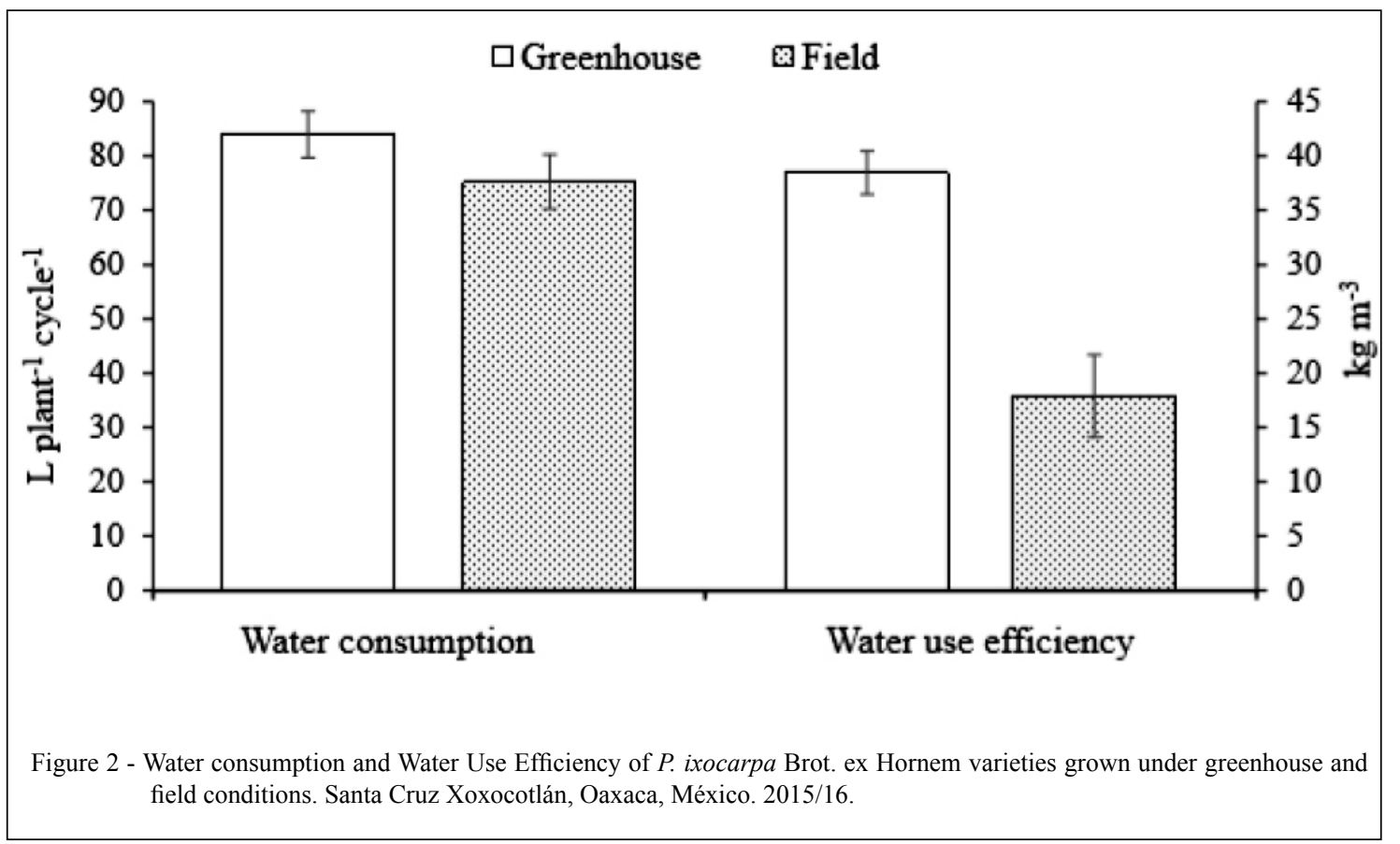

conditions produced the first fruit at 49 days after transplant (DAT). This characteristic is desirable since harvests could be earlier, and possibly more cycles per year could be grown as SÁNCHEZ \& PONCE (1998) established for S. lycopersicum L. The San Martin produced fruits 57 DAT on the field and 63 DAT in the greenhouse; this variety is considered a late-producer for field or greenhouse production. The yield reached its peak for the Rendidora at 70 DAT under both conditions; meanwhile, Tecozautla reached it at 63 DAT in the field and at 70 DAT in the greenhouse. Peak production for the San Martin was reached at 70 DAT in the greenhouse and the field. The highest yield for the four varieties and both conditions were obtained from the third to the sixth

Table 3 - Average yield patterns in four P. ixocarpa Brot. ex Hornem varieties grown under greenhouse and field conditions for seven harvests. Santa Cruz Xoxocotlán, Oaxaca, México. 2015/16.

\begin{tabular}{|c|c|c|c|c|c|c|c|c|}
\hline \multirow{3}{*}{ Variety } & \multicolumn{7}{|c|}{ 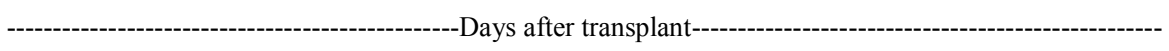 } & \multirow{2}{*}{ Total } \\
\hline & 49 & 57 & 63 & 70 & 77 & 100 & 113 & \\
\hline & \multicolumn{7}{|c|}{---------------------------------------------------Greenhouse $\left(\mathrm{kg} \mathrm{m}^{-2}\right.$ )-------------------------------------------------- } & \\
\hline Tecozautla & $0.01 \mathrm{a}^{1}$ & $0.11 \mathrm{~b}$ & $0.62 \mathrm{~b}$ & $0.98 \mathrm{~b}$ & $0.60 \mathrm{~b}$ & $1.23 \mathrm{a}$ & $0.52 \mathrm{a}$ & $4.06 \mathrm{~b}$ \\
\hline Rendidora & $0.05 \mathrm{a}$ & $0.23 \mathrm{a}$ & $0.79 \mathrm{a}$ & $1.55 \mathrm{a}$ & $0.82 \mathrm{~b}$ & $0.79 \mathrm{~b}$ & $0.62 \mathrm{a}$ & $4.84 \mathrm{a}$ \\
\hline Diamante & - & $0.11 \mathrm{~b}$ & $0.60 \mathrm{~b}$ & $0.77 \mathrm{~b}$ & $1.36 \mathrm{a}$ & $0.55 \mathrm{bc}$ & $0.56 \mathrm{a}$ & $3.95 \mathrm{~b}$ \\
\hline San Martín & - & - & $0.53 \mathrm{~b}$ & $1.05 \mathrm{~b}$ & $0.78 \mathrm{~b}$ & $0.40 \mathrm{c}$ & $0.30 \mathrm{~b}$ & $3.07 \mathrm{c}$ \\
\hline CV $(\%)$ & 7.22 & 30.21 & $10.87 \mathrm{a}$ & 19.63 & 9.51 & 13.02 & 23.74 & 9.12 \\
\hline \multicolumn{9}{|c|}{ - } \\
\hline Tecozautla & - & $0.53 \mathrm{a}$ & $0.91 \mathrm{a}$ & $0.51 \mathrm{~b}$ & $0.51 \mathrm{a}$ & $0.51 \mathrm{a}$ & $0.06 \mathrm{c}$ & $2.73 \mathrm{a}$ \\
\hline Rendidora & $0.03 \mathrm{a}$ & $0.38 \mathrm{ab}$ & $0.49 \mathrm{~b}$ & $0.41 b c$ & $0.27 \mathrm{~b}$ & $0.27 \mathrm{~b}$ & $0.18 \mathrm{~b}$ & $2.10 \mathrm{~b}$ \\
\hline Diamante & $0.04 \mathrm{a}$ & $0.21 \mathrm{bc}$ & $0.56 \mathrm{~b}$ & $0.30 \mathrm{c}$ & $0.56 \mathrm{a}$ & $0.56 \mathrm{a}$ & $0.44 \mathrm{a}$ & $2.73 \mathrm{a}$ \\
\hline San Martín & - & $0.10 \mathrm{c}$ & $0.54 \mathrm{~b}$ & $1.03 \mathrm{a}$ & $0.46 \mathrm{a}$ & $0.46 \mathrm{a}$ & $0.24 \mathrm{~b}$ & $2.40 \mathrm{~b}$ \\
\hline CV (\%) & 4.35 & 22.78 & 21.10 & 10.35 & 19.75 & 19.75 & 26.37 & 9.52 \\
\hline
\end{tabular}

${ }^{1}$ Same letter in each column is not statistically different, Tukey $(\mathrm{P} \leq 0.05) ; \mathrm{CV}$ : coefficient of variation. 
harvest. These results differ from PONCE et al. (2012) and PEÑA-LOMELI et al. (2014). They reported that the highest yield was obtained from the first harvest in the field and in the greenhouse. Contrary to PEÑA et al. (1997), the optimal period between harvests reported in this research should be similar, instead of 21 days. The Diamante was reached its peak production in the greenhouse at the 77 DAT, similar to the results reported by PEÑA et al. (1997).

\section{CONCLUSION}

The microclimate of the greenhouse with respect to the field favored a greater yield in all varieties of $P$. ixocarpa Brot. ex Hornem. Plastic covering, combined with side windows opened during the day, modified the microclimate, reduced the PAR and consequently the IPAR, and the temperature was slightly higher. This favored the efficient use of water and increased the number of fruits and yield.

\section{ACKNOWLEDGEMENTS}

The authors are grateful to the Instituto Politécnico Nacional (IPN) for the facilities to accomplish this research and the Consejo Nacional de Ciencia y Tecnología (CONACyT) for the doctoral scholarship of the first author.

\section{DECLARATION OF CONFLICTING INTERESTS}

The authors declare no conflict of interest. The founding sponsors had no role in the design of the study; in the collection, analyses, or interpretation of data; in the writing of the manuscript, and in the decision to publish the results.

\section{AUTHORS' CONTRIBUTIONS}

All authors contributed equally for the conception and writing of the manuscript. All authors critically revised the manuscript and approved of the final version.

\section{REFERENCES}

ADAMS, S.R. et al. Effect of temperature on the growth and development of tomato fruits. Annals of Botany, v.88, p.869-877, 2001. Available from: <https://doi.org/10.1006/anbo.2001.1524> Accessed: Feb. 15, 2017. doi: 10.1006/anbo.2001.1524.

BURIOL, G.A. et al. Modifying the relative air humidity by using and managing a plastic greenhouse. Revista Brasileira de Agrometeorologia, v.8, n.1, p.11-18, 2000. Available from: $<$ http://www.sbagro.org.br/bibliotecavirtual/arquivos/1222.pdf $>$. Accessed: Jan. 02, 2018. doi: 10.1590/0102-778620140094.

FAUST, J.E. First research report. Light management in greenhouses. I. Daily light integral: A useful tool for the U.S. Floriculture industry 2002. Available from: $<$ http://www. specmeters.com/assets/1/7/A051.pdf>. Accessed: Jun. 06, 2017.
FLORES, J. et al. Water Requirements for Greenhouse Tomato. Terra Latinoamericana, v.25, n.2, p.127-134, 2007. Available from: $<$ http://www.redalyc.org/pdf/573/57325204.pdf> Accessed: Jun. $08,2017$.

HASHEM, F.A. et al. Influence of greenhouse cover on potential evapotranspiration and cucumber water requirements. Annals of Agricultural Science, v.56, p.49-55, 2011. Available from: $\quad<\mathrm{https}: / /$ www.sciencedirect.com/science/article/pii/ S0570178311000029?via\%3Dihub>. Accessed: Jan. 08, 2017. doi: 10.1016/j.aoas.2011.05.001.

KORCZYNSKI, P.C., et al. Mapping monthly distribution of daily light integrals across the contiguous United States. HorTechnology, v.12, p.12-16, 2002. Available from: <http:// horttech.ashspublications.org/content/12/1/12.full.pdf + html $>$. Accessed: Jan. 08, 2017.

LOPEZ-LOPEZ, R. et al. Husk tomato (Physalis ixocarpa Brot.) production based on irrigation volume and plastic mulching. Revista Chapingo Serie Horticultura, v.15, n.1, p.83-89, 2009. Available from: <http://www.scielo.org.mx/scielo.php?script=sci arttext\&pid=S1027-152X2009000100012>. Accessed: Jan. 03, 2017.

NMX-FF-054-1982. Productos alimenticios no industrializados para uso humano, hortalizas en estado fresco, tomate con cáscara. Diario Oficial de la Federación. Norma Oficial Mexicana NMXFF-54-1982. Available from: $<$ http://dof.gob.mx/nota detalle.php ?codigo $=4788109 \&$ fecha $=31 / 12 / 1982>$. Accessed: Jul. 03, 2018.

OJODEAGUA, A.J.L. et al. Efficiency of soil and tezontle in production systems of tomato under greenhouse. Revista Fitotecnia Mexicana, v.31, n.4, p. 367-374, 2008. Available from: <http:// www.redalyc.org/pdf/610/61031409.pdf>. Accessed: Jan. 05, 2017.

PEÑA, L.A. et al. Harvest intervals of CHF1-Chapigo variety of husk tomato (Physalis ixocarpa Brot. Revista Chapingo Serie Horticultura, v.3, n.1, p.31-38, 1997. Available from: $<$ https://www. chapingo.mx/revistas/phpscript/download.php?file=completo\&id $>$. Accessed: Nov. 23, 2017.

PEÑA-LOMELI,A. etal.Agronomic performance of husk tomato varieties undergreenhouse andopenfield conditions. Revista Fitotecnia Mexicana, v.37, n.4, p.381-391, 2014. Available from: <http://www.scielo.org. $\mathrm{mx} /$ scielo.php? script $=$ sci_arttext\&pid $=\mathrm{S} 0187-73802014000400011>$. Accessed: May 12, 2017.

PONCE, V.J.J. et al. Pruning and plant density in three varieties of husk tomato (Physalis ixocarpa Brot. ex Hornem) grown under greenhouse conditions. Revista Chapingo Serie Horticultura, v.18, n.3, p. 325-332, 2012. Available from: <http://www.scielo.org.mx/ scielo.php?script $=$ sci_arttext\&pid=S1027-152X2012000300006>. Accessed: Dec. 16, 2017. doi: 10.5154/r.rchsh.2010.08.028.

RAMOS, L.C. et al. Nitrogen use efficiency in husk tomato under fertigation. Terra Latinoamericana, v.4, p.465-469, 2002. Available from: $<\mathrm{http} / /$ www.chapingo.mx/terra/contenido/20/4/art465-469.pdf $>$. Accessed: Jan. 08, 2017.

RODRÍGUEZ, A.G. et al. Greenhouse grown tomato (Solanum lycopersicum) diseases in the Central Region of Michoacan. Revista Fitotecnia Mexicana, v.29, n.1, p.50-59, 2011. Available from: <http://www.scielo.org.mx/scielo.php?script=sci arttext\&pi $\mathrm{d}=\mathrm{S} 0185$-33092011000100005>. Accessed: Mar. 13, 2017.

SAGARPA. Servicio de Información Agroalimentaria y Pesquera. Available from: <http://www.siap.gob.mx/cierre-de-laproduccion-agricola-por-cultivo/>. Accessed: May. 26, 2016. 
SÁNCHEZ, C.F.; PONCE O.J. Plantation density and decapitation level in tomato (Lycopersicon esculentum Mill.) cultivated under soilless culture. Revista Chapingo Serie Horticultura, v.4, n.2, p.89-94, 1998. Available from: < https://www.chapingo.mx/revistas/ horticultura/contenido.php?id_articulo $=761 \&$ id_revistas $=1 \&$ id revista_numero=73>. Accessed: May 28, 2017.

SANTIAGUILLO, H.J.F. et al. Aprovechamiento tradicional y moderno de tomate Physalis en México. Publicaciones de la Red de Tomate de Cáscara. 1a. edición. Prometeo Editores S.A. de C.V. ISBN: 978-607-12-0071-6. Universidad Autónoma Chapingo. Chapingo, Texcoco, Edo. de México. 2009, 31p. Available from: <https://www.researchgate.net/publication/283490255 APROVECHAMIENTO_TRADICIONAL_Y_MODERNO_DE_ TOMATE_Physalis_EN_MEXICO $>$. Accessed: Jun. 15, 2016.

SANTIAGUILLO, H.J.F. et al. Selection for fruit yield and quality from plant x plant crosses between husk tomato varieties. Revista Fitotecnia Mexicana, v.27, n.1, p.85-91, 2004. Available from: $<$ http://www.redalyc.org/html/610/61027111/>. Accessed: Dec. $15,2016$.

SEMARNAT. Especificaciones de fertilidad, salinidad y clasificación de suelos, estudios, muestreo y análisis. Diario Oficial de la Federación. Norma Oficial Mexicana NOM-021RECNAT-2000. Available from: $<$ http:// biblioteca.semarnat. gob.mx/janium/Documentos/Ciga/libros2009/DO228n.pdf >. Accessed: Nov. 15, 2017

STATISTICAL ANALYSIS SYSTEM. User's Guide, Volumes 1 and 2 SAS/ ETS 9. Institute Inc. Cary, NC, EUA. 2002, 2143p. Available from: <https://support.sas.com/documentation/ onlinedoc/91pdf/sasdoc_91/ets_ug_7314.pdf >. Accessed: Jan. $11,2016$.
URRESTARAZU, M. Tratado de cultivo sin suelo. MundiPrensa, 2004, 914p. Available from: <https://www.mundiprensa. $\mathrm{mx} /$ catalogo/9788484761396/tratado-de-cultivo-sin-suelo $>$. Accessed: Jan. 11, 2017.

VALERA, D.L. et al. Aerodynamic analysis of several insect screens used in greenhouses. Spanish Journal Agricultural Research v.4, n.4, p. 273-279, 2006. Available from: <http:// revistas.inia.es/index.php/sjar/article/view/204>. Accessed: Jul. 19, 2018. doi: 10.5424/sjar/2006044-204.

VARGAS, P.O. et al. Dietary potential of husk tomatoes (Physalis spp.) in México. Agroproductividad, v.8, n.1, p.17-22, 2015 Available from: <http://www.laniveg.com/sitio/.../Vargas-et-al2015-potencia-alimenticio-tomate.pdf $>$. Accessed: May 10, 2017.

VILLALOBOS, R.S. et al. Manejo del riego en el invernadero. IN: Castellanos, J. Z. Manual de producción hortícola en invernadero. 2 $2^{\mathrm{a}}$ Ed. INTAGRI, 2004, 469p. Available from: $<$ https://www.intagri.com/.../Manual-de-produccion-de-tomatebajo-invernadero.pdf $>$. Accessed: Dec. 10, 2017.

WANG, D. et al. Effect of soil matric potential on tomato yield and water use under drip irrigation condition. Agricultural Water Management, v.87, p.180-186, 2006. Available from: <https:// www.sciencedirect.com/science/article/pii/S0378377406002034>. Accessed: Dec. 09, 2017. doi: 10.1016/j.agwat.2006.06.021.

ZHANG, H.X. et al. Yield and quality response of cucumber to irrigation and nitrogen fertilization under subsurface drip irrigation in solar greenhouse. Agricultural Sciences in China, v.10, p.921930, 2011. Available from: <https://www.sciencedirect.com/ science/article/pii/S1671292711600771>. Accessed: Feb. 15, 2017. doi:_10.1016/S1671-2927(11)60077-1. 